\title{
Interaction of Poly(4-vinylpyridine) with Copper Surfaces: Electrochemical, Thermal and Spectroscopic Studies
}

\author{
Cristiano Giacomelli ${ }^{a}$, Fernando Carlos Giacomelli $^{a}$, Adriana Lídia Santana $^{b}$, Vanessa Schmidt $^{b}$, \\ Alfredo Tiburcio Nunes Pires ${ }^{b}$, José Roberto Bertolino ${ }^{b}$ and Almir Spinelli ${ }^{*, a}$ \\ ${ }^{a}$ Grupo de Estudos de Processos Eletroquímicos e Eletroanalíticos and ${ }^{b}$ Laboratório de Materiais Poliméricos, \\ Departamento de Química, Universidade Federal de Santa Catarina, 88040-900 Florianópolis-SC, Brazil
}

\begin{abstract}
A interação do polímero poli(4-vinilpiridina) (P4VP) e íons tiocianato com cobre em soluções ácidas foi estudada através de voltametria cíclica, termogravimetria, análise elementar e espectroscopia na região do infravermelho. Observou-se que os íons $\mathrm{Cu}(\mathrm{I})$ eletrogerados em $c a$. $-0,45 \mathrm{~V} / \mathrm{ECS}$ na superfície do eletrodo promovem uma reação de complexação com $\mathrm{P} 4 \mathrm{VP}$ e $\mathrm{SCN}^{-}$, ambos presentes em solução. O complexo polimérico eletroativo resultante cresce sobre a superfície do eletrodo como um filme e o centro metálico é oxidado para $\mathrm{Cu}$ (II) numa etapa subseqüente em ca. -0,23 V/ECS. De acordo com os resultados termogravimétricos, o complexo obtido é menos estável do que o P4VP puro, conforme indicado pelo abaixamento da temperatura inicial de degradação de $c a .400{ }^{\circ} \mathrm{C}$ (P4VP) para ca. $200^{\circ} \mathrm{C}$ (complexo). A análise elementar do filme revelou uma composição química de 2:1:2 para $\mathrm{P} 4 \mathrm{VP}: \mathrm{Cu}: \mathrm{SCN}^{-}$e os espectros na região do infravermelho indicaram que tal complexo polimérico é formado por um centro metálico de cobre coordenado pelos átomos de nitrogênio dos anéis piridínicos e íons tiocianato.
\end{abstract}

\begin{abstract}
The interaction of poly(4-vinylpyridine) (P4VP) and thiocyanate ions with copper in acid solutions was studied by cyclic voltammetry, thermogravimetry, elemental analysis and infrared spectroscopy. It is shown that at $c a .-0.45 \mathrm{~V} / \mathrm{SCE}$ the electrogenerated $\mathrm{Cu}(\mathrm{I})$ ions at the surface of a copper electrode induce a complexing reaction with $\mathrm{P} 4 \mathrm{VP}$ and $\mathrm{SCN}^{-}$both present in solution. The resulting electroactive polymer-complex grows onto the electrode surface as a film, and the metallic center is further oxidized to $\mathrm{Cu}$ (II) in a subsequent step at $c a$. $-0.23 \mathrm{~V} / \mathrm{SCE}$. According to thermogravimetric results, the polymer-complex is less thermally-stable than $\mathrm{P} 4 \mathrm{VP}$ as evidenced by the lowering in the initial temperature of degradation from $c a .400{ }^{\circ} \mathrm{C}$ (P4VP) to $c a .200^{\circ} \mathrm{C}$ (complex). The elemental analysis revealed a chemical composition of 2:1:2 for P4VP:Cu:SCN, and the infrared spectra indicated that the complex comprises a copper metallic center coordinated with nitrogen pyridinic rings (P4VP) and thiocyanate ions.
\end{abstract}

Keywords: poly(4-vinylpyridine), polymeric films, copper

\section{Introduction}

By physically mixing transition-metal cations and polymers, it has been possible to obtain the so-called synthetic macromolecule-metal complexes (MMC) as final resulting products, ${ }^{1}$ which present quite different properties from those of the individual bulk components. ${ }^{2,3}$ Since the development of synthetic procedures with the objective of obtaining new polymers, blends and composites with specific properties and technologic applications has been one of the prime targets in the new materials research field, ${ }^{4}$ the mixture of transition-metals and polymers is, indeed, a

* e-mail: spin@qmc.ufsc.br very promising strategy to achieve several desired material features. Recently, Schmelz and Rehahn emphasized the importance in developing transition-metal coordination polymers because of their optical, magnetic, electronic and solution properties. ${ }^{5}$ Additionally, it is known that in some cases, d-block salts may act as compatibilizers for copolymers that would be otherwise immiscible. ${ }^{6}$ Our research group previously demonstrated the new properties of poly(vinylpyridine) when it forms a polymer-complex with Zn(II) ions. ${ }^{7}$ The polymer poly (4-vinylpyridine) (P4VP) exhibited different thermal and conducting properties as a $[\mathrm{P} 4 \mathrm{VP}] /$ copper iodide binary mixture; the electrical conductivity changes drastically with the increase in the amount of copper iodide in the blends. ${ }^{8}$ Specifically, the 
couple P4VP/copper has been focused elsewhere ${ }^{1,3,6,10-15}$ due its great potential for applications such as in reactive blending, ${ }^{6}$ catalyst for determination and oxidation of ascorbic $\operatorname{acid}^{9}$ and the technically important oxidative polymerization of 2,6-dimethylphenol ${ }^{1}$ in addition to the selective conversion of 2,3,6-trimethylphenol and related compounds to $p$-benzoquinones,,$^{10}$ cation exchange resins designed to remove or preconcentrate metals from dilute solutions by binding them to soluble polymers, ${ }^{11}$ solid-state electrochemical cells, ${ }^{12}$ anti-corrosion methods ${ }^{13}$ and circuit manufacturing on microscopic smoothly polymeric surfaces or production of polymeric films on metallic surfaces. ${ }^{14}$ Consequently, the importance in obtaining P4VP/copper films onto copper surfaces for technological development is clear. Thereby, it is feasible to carry out the synthesis of this transition-metal polymer-complex by employing electrochemical methods through generation of copper cations from the oxidation of a bare copper electrode immersed in a P4VP containing solution. We have observed a dark green film resulting from the interaction of P4VP and copper surfaces when the working solution contained potassium thiocyanate in either open circuit potential conditions (spontaneous film growth) or not (electrochemically generate copper ions). ${ }^{15}$ The goal of this work is to explore the electrochemical formation of this film as well as its thermal behavior, composition and structure characteristics.

\section{Experimental}

\section{Chemicals}

All the reagents used were of analytical grade acquired from Scientific Polymer Products (poly(4-vinylpyridine), linear, MW $200000 \mathrm{~g} \mathrm{~mol}^{-1}$ ), Merck (potassium thiocyanate), Ecibra Reagentes Analíticos (acetic acid) and Biotec (cupric sulfate). All of them were used without previous purification. Distilled and deionized water was used for all solution preparations.

\section{Electrochemical system}

The electrochemical measurements were carried out with a Voltalab PGZ100 Radiometer Copenhagen potentiostat interfaced with a microcomputer using the VoltaMaster 4.0 software for data acquisition and analysis. The electrochemical cell contained five openings: three of them were used for the electrodes and two for nitrogen bubbling in the solutions during all the experiments. The counter electrode was a graphite rod and the reference electrode was a saturated calomel electrode (SCE) connected to the cell by a bridge and a Luggin-Habber capillary. All potentials in the text are quoted versus this reference electrode. The working electrode was a $0.52 \mathrm{~cm}^{2}$ copper plate $(99.99 \%)$ mounted in a glass tube with Araldite $^{\circledR}$ epoxy. Prior to the experiments, the electrode surface was polished with emery paper followed by $1.0 \mu \mathrm{m}$ and $0.05 \mu \mathrm{m}$ alumina. Subsequently the electrode was cleaned ultrasonically, degreased with acetone, rinsed with deionized water and air-dried. Experiments were made using repetitive (RTPS) or single (STPS) triangular potentiodynamic scans between the cathodic $(-1.05 \mathrm{~V})$ and anodic $(+1.00 \mathrm{~V})$ switching potential limits $\left(\mathrm{E}_{\lambda, \mathrm{c}}\right.$ and $\mathrm{E}_{\lambda, \mathrm{a}}$, respectively) and other different potential/time perturbations, which will be indicated for each particular case. The working solution was a mixture of acetic acid, potassium thiocyanate and $\mathrm{P} 4 \mathrm{VP}$ with corresponding concentrations of $3 \%, 0.1 \mathrm{~mol} \mathrm{~L}^{-1}$ and $0.1 \mathrm{~mol} \mathrm{~L}^{-1}$, respectively. All solutions were purged with nitrogen for 8 minutes. The experiments were done at $25 \pm 01{ }^{\circ} \mathrm{C}$.

\section{Film characterization}

Depending on the experimental parameters, a dark green film was obtained, which contained P4VP, thiocyanate anions and copper cations originate from the copper electrode in the electrochemical cell. The fact that the film was green-colored suggested that $\mathrm{Cu}$ (II) was the predominant oxidation state, provided that a $\mathrm{Cu}(\mathrm{I})$-film would be colorless since no d-d electronic transitions are feasible to take place in a $\mathrm{d}^{10}$ system, and metal-to-ligand charge transfer possible for a $\mathrm{d}^{10}$ complex with aromatic structures also does not occur in the visible region of the spectrum.

The electrosynthesized film had its structure and composition studied by infrared spectroscopy (PerkinElmer FT-IR 16PC), elemental (CE Instruments CHNS E.A. $1100)$ and thermogravimetric analysis. In the later case, the curves were recorded in a Shimadzu TGA-50 apparatus with a heating rate of $10{ }^{\circ} \mathrm{C} \mathrm{min}{ }^{-1}$ under nitrogen atmosphere. For the sake of comparison, polymer-complex films with different proportions in molar ratio were also prepared by casting (without assistance of redox chemistry). In this case, mixtures with a molar percentage of the polymer monomeric unit $(0.5 \mathrm{~g}$ to $15 \mathrm{~mL} 3 \%$ acetic acid) and appropriate aqueous solutions containing cupric sulfate and potassium thiocyanate were stirred continuously for about $24 \mathrm{~h}$. The homogeneous solutions were left to allow solvent evaporation in polystyrene leveled plates at room temperature for $48 \mathrm{~h}$, and then the resulting films were washed with distilled water, filtered and vacuum dried. 


\section{Results and Discussion}

\section{Film growth}

Figure 1 shows a cyclic voltammogram obtained at scan rate $(v)$ of $10 \mathrm{mV} \mathrm{s}^{-1}$ for a copper stationary electrode immersed in an aqueous solution containing $3 \%$ acetic acid (added for dissolution purposes), $0.10 \mathrm{~mol} \mathrm{~L}^{-1}$ both KSCN and P4VP. In such conditions, three oxidation peaks are present $\left(\mathrm{E}_{\mathrm{p}}^{\mathrm{I}}=-0.45 \mathrm{~V} ; \mathrm{E}_{\mathrm{p}}{ }^{\mathrm{II}}=-0.30 \mathrm{~V}\right.$ and $\left.\mathrm{E}_{\mathrm{p}}{ }^{\mathrm{II}}=-0.23 \mathrm{~V}\right)$, whereas in the reverse going scan it is possible to observe one reactivation peak $\left(\mathrm{E}_{\mathrm{p}}^{\mathrm{IV}}=-0.09 \mathrm{~V}\right)$ and two well-defined reduction processes $\left(\mathrm{E}_{\mathrm{p}}^{\mathrm{V}}=-0.59 \mathrm{~V}\right.$ and $\left.\mathrm{E}_{\mathrm{p}}^{\mathrm{VI}}=-0.74 \mathrm{~V}\right)$. This cyclic voltammogram showed a huge difference from that one obtained in absence of the polymer, which is shown in the inset in Figure 1. In this later case, the profile is in agreement with those reported by several authors, ${ }^{16-20}$ who investigated the electrochemistry of $\mathrm{Cu} / \mathrm{SCN}$ system. It is well-known that the oxidation of $\mathrm{Cu}(0)$ to $\mathrm{Cu}(\mathrm{I})$ takes place at A1 (Figure 1 - inset), and is forwarded by the $\mathrm{CuSCN}$ formation. Figueroa et al. ${ }^{16}$ proposed the following mechanism for the first oxidation peak of the $\mathrm{Cu} / \mathrm{SCN}$ system:

$\mathrm{Cu}+\mathrm{SCN}^{-} \rightarrow \mathrm{Cu}\left(\mathrm{SCN}^{-}\right)_{\mathrm{ad}}$ $\mathrm{Cu}\left(\mathrm{SCN}^{-}\right)_{\mathrm{ad}} \rightarrow \mathrm{Cu}(\mathrm{SCN})_{\mathrm{ad}}+\mathrm{e}$

$\left[\mathrm{Cu}(\mathrm{SCN})_{\mathrm{ad}}\right]_{\mathrm{n}} \rightarrow \mathrm{nCuSCN}_{(\mathrm{s})}$

$\mathrm{Cu}(\mathrm{SCN})_{\mathrm{ad}}+2 \mathrm{SCN}^{-} \rightarrow \mathrm{Cu}(\mathrm{SCN})_{3}^{2-}=\mathrm{CuSCN}_{(\mathrm{s})}+2 \mathrm{SCN}^{-}$

Likely, the formation of oxides, oxyhydroxides and hydroxides also occurs in this region, ${ }^{18}$ but not as the main reactions. The charge transfer process related to peak $\mathrm{A} 1$ underwent considerable changes due to the presence of

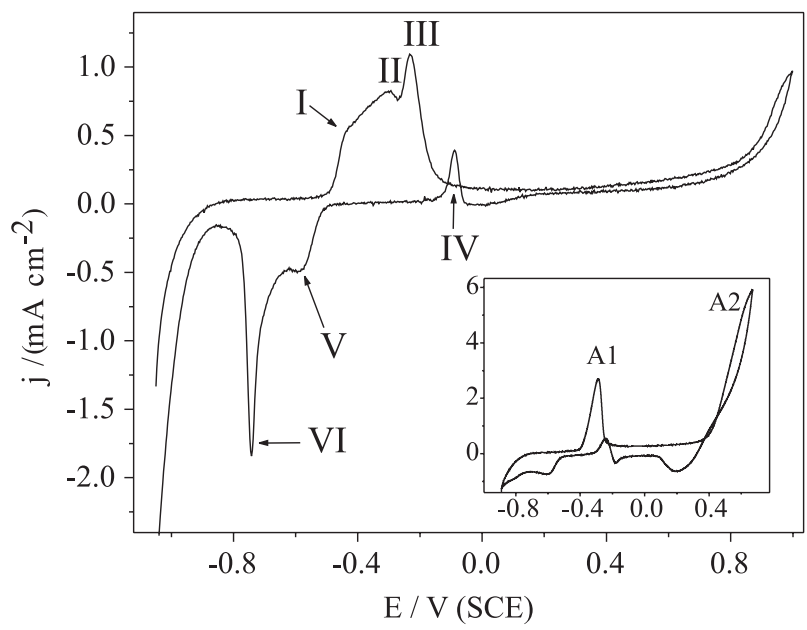

Figure 1. Cyclic voltammogram of a copper stationary electrode immersed in aqueous solution containing 3\% acetic acid, $0.10 \mathrm{~mol}$ $\mathrm{L}^{-1}$ both KSCN and P4VP at $v=10 \mathrm{mV} \mathrm{s}^{-1}$. The inset shows a cyclic voltammogram in absence of P4VP.
$\mathrm{P} 4 \mathrm{VP}$, as it will be discussed hereinafter. At more anodic potentials than peak $\mathrm{A} 1$, the already reported peak $\mathrm{A} 2$, which is attributed to $\mathrm{Cu}(\mathrm{SCN})_{2}$ formation from the cuprous thiocyanate salt, appears. At these potentials a competition between transpassivation and repassivation occurs. ${ }^{17}$ Moreover, when the localized corrosion phenomenon takes place, it is related to the nucleation and growth of an unstable $\mathrm{Cu}(\mathrm{SCN})_{2}$ layer in equilibrium with $\mathrm{Cu}(\mathrm{SCN})_{3}{ }^{-18}$

If we compare the two anodic scans (Figure 1 and the inset), we will notice a significant decrease in the anodic current density, which earliest means the P4VP acts in diminishing the reaction kinetics of copper oxidation. Two new peaks come into view at the peak A1 potential range, which is associated to cuprous species. To better understand these processes and establish the relationship between each voltammetric signal, ${ }^{21}$ the influence of the anodic switching potential $\left(\mathrm{E}_{1,2}\right)$ on the voltammetric profile was investigated.

Figure 2A shows the cyclic voltammograms obtained with different anodic switching potentials $\left(\mathrm{E}_{\lambda, \mathrm{a}}\right)$. A freshly prepared copper electrode was used to acquire each cycle. Figure 2B and 2C show the first cycle and the zoon of all cathodic going scans, respectively. From Figure 2A, it is possible to observe that when $\mathrm{E}_{\lambda, \mathrm{a}} \leq \mathrm{E}_{\mathrm{p}}{ }^{\mathrm{I}}$ (cycle a - detailed in the Figure 2B) there is only one reduction process in the reverse scan (peak VI). Therefore, the conjugated peaks I and VI are related to the following electrochemical reactions involving copper species:

peak I (oxidation): $\mathrm{Cu}(0) \rightarrow \mathrm{Cu}(\mathrm{I})+\mathrm{e}^{-}$

peak VI (reduction): $\mathrm{Cu}(\mathrm{I})+\mathrm{e}^{-} \rightarrow \mathrm{Cu}(0)$

This behaviour is identical to the previous reported results for $\mathrm{E}_{\lambda, \mathrm{a}}$ influence on the $\mathrm{Cu} /$ thiocyanate system. ${ }^{20}$

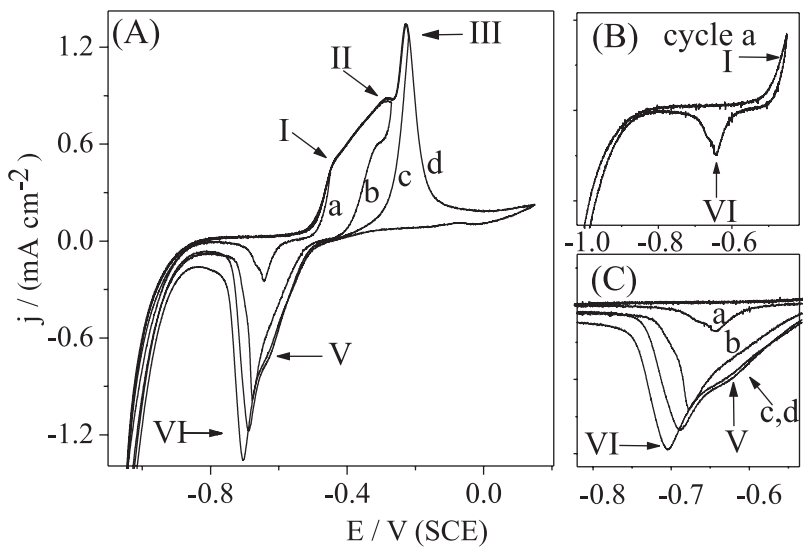

Figure 2. (A) Cyclic voltammograms of a copper stationary electrode immersed in aqueous solution containing 3\% acetic acid, $0.10 \mathrm{~mol} \mathrm{~L}^{-1}$ both KSCN and P4VP obtained at $v=10 \mathrm{mV} \mathrm{s}^{-1}$ for different anodic switching potentials $\left(\mathrm{E}_{\lambda, \mathrm{a}}\right)$; (B) Cyclic voltammogram obtained with $\mathrm{E}_{\lambda, \mathrm{a}}$ barely equal to $\mathrm{E}_{\mathrm{p}}^{\mathrm{I}}$, (C) zoon of all reduction process as function of $\mathrm{E}_{\lambda, \mathrm{a}}$ 
Increasing $\mathrm{E}_{\lambda, \mathrm{a}}$ to values equal to $\mathrm{E}_{\mathrm{p}}^{\mathrm{II}}$ (or lower) no additional reduction come into view (Figure 2C, cycle b), but when $\mathrm{E}_{1, \mathrm{a}}$ is close to $\mathrm{E}_{\mathrm{p}}^{\mathrm{III}}$ a correspondent backward reaction can be observed at peak V (Figure 2C, cycles c, d). This behaviour suggests that copper species are not oxidized at peak II, whereas the peaks III and V are associated to the following reactions:

peak III (oxidation): $\mathrm{Cu}(\mathrm{I}) \rightarrow \mathrm{Cu}(\mathrm{II})+\mathrm{e}^{-}$

peak $\mathrm{V}$ (reduction): $\mathrm{Cu}(\mathrm{II})+\mathrm{e}^{-} \rightarrow \mathrm{Cu}(\mathrm{I})$

The oxidation peak in the cathodic scan (peak IV Figure 1) is $\mathrm{E}_{\lambda, \mathrm{a}}$-dependent but is not inherent to the P4VP/ $\mathrm{Cu} / \mathrm{SCN}$ system; it is also present in absence of P4VP (Figure 1, inset) and because of that it is discussion is beyond our goal in this article. The Cu/P4VP/SCN polymer-complex can be obtained by mixing its components (cuprous or cupric salt, thiocyanate salt and the polymer), as described in the experimental section. Therefore, it is feasible to propose the formation a polymercomplex at peak I as the reason for the changes in the voltammetric profile in presence of P4VP. Therefore, after $\mathrm{Cu}(\mathrm{I})$ is generated in the electrochemical cell at the electrode surface there occurs a complexing reaction involving $\mathrm{Cu}(\mathrm{I}), \mathrm{P} 4 \mathrm{VP}$ and $\mathrm{SCN}^{-}$, and the resulting polymer-complex grows onto the electrode surface as a film. This film reduces the copper oxidation (reaction 5) due to the surface blockage as characterized by the decrease in the anodic current density at the first oxidation process in presence of P4VP (see Figure 1). Besides this complexing reaction, which is the main one taking place at peak I in $\mathrm{P} 4 \mathrm{VP}$ and $\mathrm{SCN}^{-}$containing solutions, there exists a competition with the reactions $1-4$ for $\mathrm{Cu}(\mathrm{I})$ species.

To better recognize the presence of a homogeneous chemical reaction following the cuprous ion formation, several cyclic voltammograms were recorded as function of scan rate. Figure 3 shows the cyclic voltammograms obtained at different scan rates of a copper stationary electrode immersed in an aqueous solution containing 3\% acetic acid, $0.10 \mathrm{~mol} \mathrm{~L}^{-1}$ both KSCN and P4VP. In this figure, it is possible to observe that the peak I becomes gradually more clear with the decrease in the scan rate from $100 \mathrm{mV} \mathrm{s}^{-1}$ (Figure 3 - inset) to $5 \mathrm{mV} \mathrm{s}^{-1}$ (Figure 3). It is also possible to observe a gradual disappearance of peak II, so that for $v=5 \mathrm{mV} \mathrm{s}^{-1}$ it can not be observed anymore. Such experimental results are attributable to a partial electrode passivation due to the polymer-complex film. Moreover, if we compare the peak I current density in Figure $1\left(0.1 \mathrm{~mol} \mathrm{~L}^{-1} \mathrm{P} 4 \mathrm{VP}\right)$ with the same peak in the inset of Figure 1, we will observe a value about six-fold lower in presence of P4VP than in absence of the polymer, which

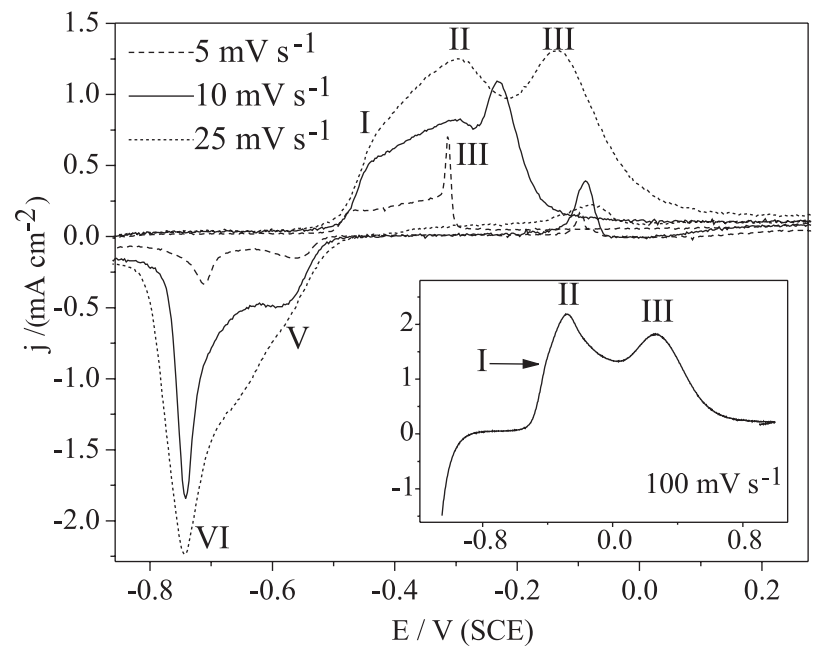

Figure 3. Cyclic voltammograms of a copper stationary electrode immersed in aqueous solution containing $3 \%$ acetic acid, $0.10 \mathrm{~mol} \mathrm{~L}^{-1}$ both KSCN and P4VP at different scan rates $(v)$. The inserted frame shows an anodic going scan at moderated high $\mathrm{v}\left(100 \mathrm{mV} \mathrm{s}^{-1}\right)$.

corroborates the passivation effect. Once the peak II does not correspond to the oxidation of copper species (as above discussed) and no other electroactive species are present in the studied potential range, it is reasonable to consider that the peak II corresponds to a time-dependent passivation effect. At low scan rates (e.g. $5 \mathrm{mV} \mathrm{s}^{-1}$ - Figure 3 ) no gradual current density increase takes place at the potential range between peak I and peak III due to the formation of a passivating polymer-complex. However, this is not true for moderated to high scan rates, as can be perceive in the inset of Figure 3 where the current density continues to increase after peak I because of the timedependent film growth. In this work, the electrochemical process at peak I was characterized as diffusion-controlled due to the behavior of the current density as a function of the scan rate $\left(\delta \log \left(\mathrm{j}_{\mathrm{p}}\right) / \delta \log (v) \approx 0.5\right){ }^{22}$

\section{Film characterization}

Figure 4 shows the optical micrograph of a copper electrode submitted to fifteen voltammetric cycles for identical experimental conditions as those in Figure 1, but at $v=5 \mathrm{mV} \mathrm{s}^{-1}$. A part of the film was mechanically removed to better verify its presence onto the electrode surface, which can be clearly seen in the Figure 4 . The chemical composition of the film and its structure were studied by elemental and thermal analysis and infrared spectroscopy. For this purpose, the film was potentiostatically obtained through electrode polarization at peak I for $5 \mathrm{~min}$. Then, the film was removed, rinsed with distilled water and vacuum dried. Although the applied potential is hardly enough to provoke the oxidation of 
$\mathrm{Cu}(0)$ to $\mathrm{Cu}(\mathrm{I})$, the resulting dark green film suggests a $\mathrm{Cu}$ (II) metallic center instead of $\mathrm{Cu}$ (I) on account of the metal electronic properties. Efforts to prepare polymercomplexes with $\mathrm{Cu}(\mathrm{I}) / \mathrm{P} 4 \mathrm{VP} /$ thiocyanate were unsuccessful inasmuch as the resulting cuprous polymer-complex (which is not colored) undergoes oxidation to produce the dark green cupric polymer-complex during the handling procedures.

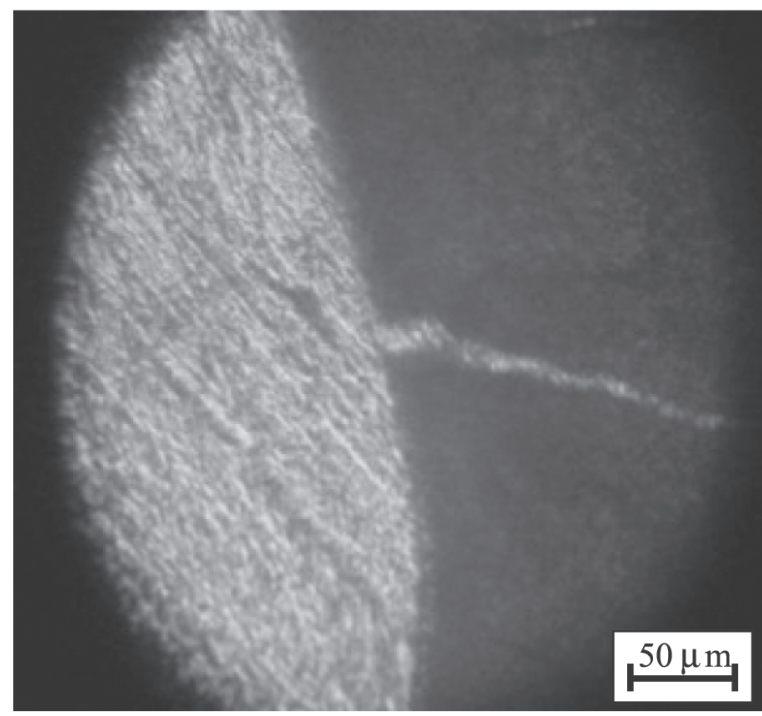

Figure 4. Optical micrograph of a copper electrode submitted to fifteen voltammetric cycles in identical experimental conditions to those described in the Figure 1, but at $v=5 \mathrm{mV} \mathrm{s}^{-1}$.

Figure 5 shows the relationship of the residual weight fraction to temperature for pure P4VP (curve a) and both P4VP polymer-complex obtained through casting (25:25:50 P4VP:Cu(II):SCN - curve b) and an electrode

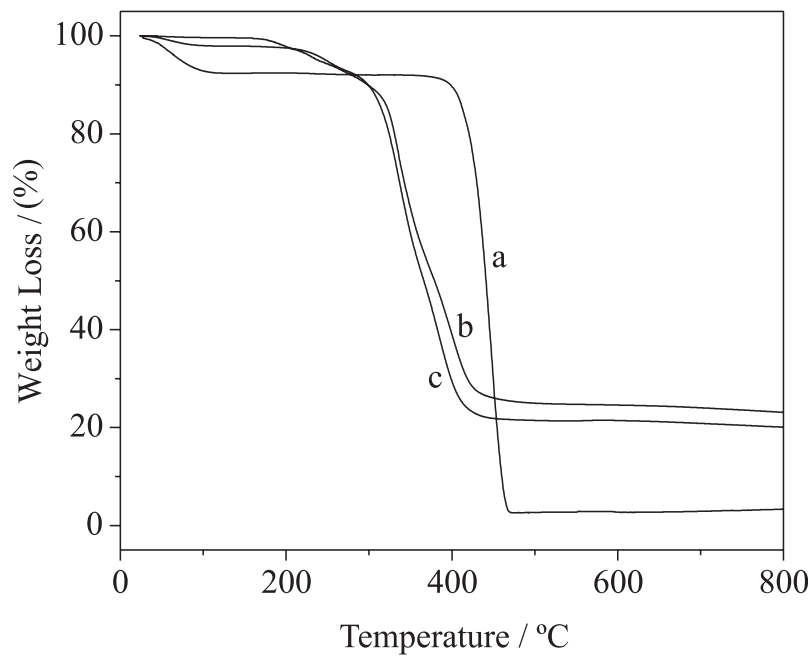

Figure 5. Thermogravimetric curves of pure P4VP (a) and both P4VP polymer-complex obtained through physical mixing of components - (25:25:50 P4VP:Cu(II):SCN) (b) and an electrode film (c) at heating rate of $10{ }^{\circ} \mathrm{C} \mathrm{min}^{-1}$ under nitrogen atmosphere. film (curve c) at heating rate of $10^{\circ} \mathrm{C} \mathrm{min}^{-1}$. The thermogram of pure P4VP shows the first weight loss between $80{ }^{\circ} \mathrm{C}$ and $100{ }^{\circ} \mathrm{C}$ by reason of the presence of water. A second and total weight loss process takes place at the temperature range $400-470{ }^{\circ} \mathrm{C}$. The curves for the polymer-complexes are very similar with a slightly weight loss for the electrode film at approximately $100{ }^{\circ} \mathrm{C}$ due to the water. For both of the polymeric complexes (curves b and c), the main degradation stage starts at $\mathrm{ca} .200{ }^{\circ} \mathrm{C}$ and finishes at ca. $400{ }^{\circ} \mathrm{C}$ with a augmentation in its intensity at $300{ }^{\circ} \mathrm{C}$ (see Figure 5). In this temperature range the degradation of both P4VP and thiocyanate ion occurs. Therefore, the polymer-complexes are less thermally-stable than P4VP as evidenced by the lowering in the initial temperature of degradation from $\mathrm{ca} .400{ }^{\circ} \mathrm{C}$ (P4VP) to ca. $200{ }^{\circ} \mathrm{C}$ (complex). The reduction in degradation temperature is probably due to complexation of the pyridine rings with $\mathrm{Cu}(\mathrm{II})$ ions which induces significant changes in the electronic density of the ring. This can be observed in the displacement of $\mathrm{C}-\mathrm{N}$ stretching in the pyridinic ring for larger wavenumbers (see below). These electronic density changes can provoke a weakening of the chemical bonds in the pyridine ring and polymeric backbone chain with a consequent reduction in thermal stability. ${ }^{23}$ Thermal degradation studies of the polymer-complexes at $350{ }^{\circ} \mathrm{C}$ under nitrogen atmosphere indicated copper sulfide as decomposition product, which is stable even above 400 ${ }^{\circ} \mathrm{C}$. The molar ratio P4VP:Cu:SCN: $\mathrm{H}_{2} \mathrm{O}$ was estimated to be $2: 1: 2: 2$. This estimative was further corroborated by elemental analysis, obtaining the following amounts of carbon, sulfur, hydrogen and nitrogen, respectively: 45.22 , $12.90,4.31$ and $13.08 \%$.

Concerning the actual and overall electrode film composition that is responsible for the observed voltammetric profile, we do not believe in a simple component but that the film contains the polymer complex as the major and superficial constituent in addition to those proposed by Figueroa et al. ${ }^{16}$ for the $\mathrm{Cu} / \mathrm{SCN}$ system, who considered both the cuprous thiocyanate, oxyhydroxides and oxides.

Figure 6 shows the FTIR spectra for pure P4VP (spectrum a), for polymer-complexes prepared physically mixing different molar ratios of its components (spectra $b$ and c) and for the electrochemically growth film at $-0.45 \mathrm{~V}$ (spectrum d). A roughly analysis at glance shows an almost total coincidence of vibrational frequencies for all polymercomplexes (spectra b to d). The characteristic stretching of pyridine rings (detailed in Figure 6B) occurs at $c a .1600$ $\mathrm{cm}^{-1}$ for pure P4VP. However, in presence of copper ions from either copper solutions (spectra b and c) or electrochemically generated through electrode oxidation 
(spectrum d) - this vibration mode is shifted to $1618 \mathrm{~cm}^{-1}$ suggesting coordination between the pyridinic nitrogen atoms and the copper metallic center. ${ }^{23,24}$ The thiocyanate was observed at ca. $2076 \mathrm{~cm}^{-1}$. Thiocyanate ions coordinated to metallic centers through sulfur atoms exhibit the $\mathrm{C}-\mathrm{N}$ stretching at wavenumber higher than $2100 \mathrm{~cm}^{-1}$ whereas those coordinated via nitrogen atoms exhibit the $\mathrm{C}-\mathrm{N}$ stretching lower than $2050 \mathrm{~cm}^{-1}{ }^{25}$ The authors consider that this rule must be cautiously applied since the $v(\mathrm{C}-\mathrm{N})$ can be affected by many others factors such as stereochemistry. Thus, the frequency $2076 \mathrm{~cm}^{-1}$ makes difficult its attribution, but given the affinity of $\mathrm{Cu}$ (II) with nitrogen atoms, ${ }^{26}$ this vibrational band suggests that coordination occurs between the $\mathrm{Cu}$ (II) ion and thiocyanate through the nitrogen atom. The shoulder at c.a. $2150 \mathrm{~cm}^{-1}$ (spectrum b) is due to the presence of cupric thiocyanate. This stretching disappears when the solid is consecutively rinsed with water.

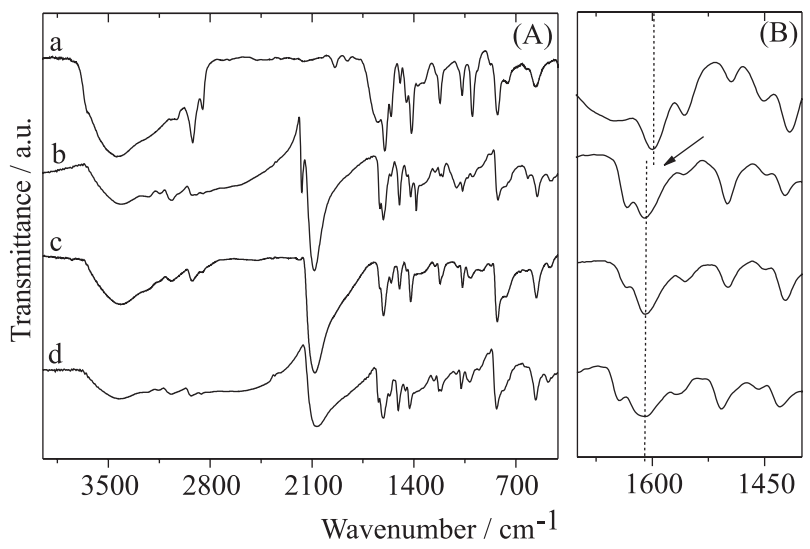

Figure 6. (A) FTIR spectra of pure P4VP (a) and both P4VP polymer-complex obtained through physical mixing of components at different proportions of $\mathrm{P} 4 \mathrm{VP} / \mathrm{Cu} / \mathrm{SCN}(25: 25: 50)$ (b), (40:20:40) (c) and an electrode film (d); (B) Expanded region of pyridinic stretching focusing on its shift to higher wavenumbers upon complexation.

\section{Conclusions}

According to the results herein presented, the polymer poly(4-vinylpyridine) provokes remarkable changes to the $\mathrm{Cu} / \mathrm{SCN}$ voltammetric profile. The cyclic voltammograms recorded in the potential range $-1.05 \mathrm{~V}-1.00 \mathrm{~V}$ either in presence of P4VP or not, exhibit the first charge transfer process at $-0.45 \mathrm{~V} / \mathrm{SCE}$. This electrochemical oxidation is related to $\mathrm{Cu}(\mathrm{I})$ formation from $\mathrm{Cu}(0)$. For $\mathrm{P} 4 \mathrm{VP}$ free solution the main resulting product is $\mathrm{CuSCN}$, however when the polymer $\mathrm{P} 4 \mathrm{VP}$ is added to the system the cuprous ions induce a complexing reaction among $\mathrm{Cu}(\mathrm{I}), \mathrm{P} 4 \mathrm{VP}$ and $\mathrm{SCN}^{-}$. The resultant polymer-complex grows onto the electrode surface as a slightly adherent dark green film. The thermogravimetric results suggested that the polymer-complex is less thermallystable than P4VP as evidenced by the lowering in the initial temperature of degradation from ca. $400{ }^{\circ} \mathrm{C}(\mathrm{P} 4 \mathrm{VP})$ to $c a$. $200{ }^{\circ} \mathrm{C}$ (complex). The elemental analysis revealed a chemical composition of 2:1:2 for P4VP:Cu:SCN, and the infrared spectra indicated that the complex comprises a copper metallic center coordinated with nitrogen pyridinic rings (P4VP) and thiocyanate ions. The P4VP plays a significant role diminishing the current density all over the potential range studied, which means that it may have application as dissolution inhibitor, in addition to the polymeric films technology.

\section{Acknowledgments}

The authors are grateful to Conselho Nacional de Desenvolvimento Científico e Tecnológico (CNPq, Brazil) for financial support. C.G. thanks to Coordenação de Aperfeiçoamento de Pessoal de Nível Superior (CAPES, Brazil) for the scholarship.

\section{References}

1. Jeschke, G.; J. Phys. Chem. B. 2000, 104, 8382.

2. Pronab, D. K.; Ruzmaikina, I.; Belfiore, L. A.; J. Polym. Sci. 2000, 38, 1931.

3. Acar, N.; Tulun, T.; Eur. Polym. J. 2001, 37, 1599.

4. Paul, D. R.; Polymer Blends, Academic Press Inc.: London, 1978.

5. Schmelz, O.; Rehahn, M.; e-Polymers 2002, no. 047.

6. Belfiore, L. A.; Mccurdie, M. P.; J. Polym. Sci., Part B: Polym. Phys. 1995, 33, 105.

7. Pires, A. T. N. ; Cheng, C. ; Belfiore, L.A.; Polym. Mater. Sci. Eng. 1989, 61, 466.

8. Rodrigues, J. R. S.; Mangrich, A. S.; Soldi, V.; Bertolino, J. R.; Pires, A. T. N.; Adv. Polymer Tech. 2000, 19, 113.

9. Lee, S. K.; Suh, J. K.; Koo, K. M.; Jeon, I. R.; Kim, W. S.; Polymer-Korea 2000, 24, 252.

10. Takaki, K.; Shimasaki, Y.; Shishido, T.; Takehira, K.; Bull. Chem. Soc. Jpn. 2002, 75, 311.

11. Sasaki, Y.; Tagashira, S.; Murakami, Y.; Fujiwara, I.; Hayashi, K.; Bunseki Kagaku 1994, 43, 111.

12. Kang, E. T.; Ong, Y. K.; Solid State Commun. 1986, 57, 587.

13. Abed, Y.; Arrar, Z.; Hammouti, B.; Taleb, M.; Kertit, S.; Mansri, A.; Anti-Corros. Method Mater. 2001, 48, 308.

14. Eisch, J. J.; Laskowski, J.; Bielinski, J.; Boleslawski, M. P.; J. Mat. Sci. Lett. 1995, 14, 146.

15. Giacomelli, C.; Giacomelli, F.C.; Schmidt, V.; Santana, A. L.; Pires, A. T. N.; Bertolino, J. R.; Spinelli A.; Proceedings of the XIII Simpósio Brasileiro de Eletroquímica e Eletroanalítica, Araraquara, Brazil, 2002. 
16. Figueroa, M. G.; Salvarezza, R. C.; Arvia, A. J.; Electrochim. Acta 1986, 31, 671.

17. Wey, A.; Abramovich, M.; D’Alkaine, C.V.; J. Electroanal. Chem. 1984, 165, 147.

18. Drogowska, M.; Brossard L.; Ménard H.; Surf. Coat. Technol. 1998, 34, 383.

19. Melendres, C.A.; O’Leary, T. J.; Solis, J.; Electrochim. Acta 1991, 36, 505.

20. Son, Y.; Tacconi, N.R.; Rajeshwar, C.; J. Electroanal. Chem. 1993, 345, 135.

21. Guzmán, R. S. S.; Vilche, J. R.; Arvía, A. J.; Electrochim. Acta 1979, 24, 395.
22. Bard, A. J.; Faulkner, L. R.; Electrochemical Methods, Fundamentals and Applications, John Wiley \& Sons Inc.: New York, 1980.

23. Santana, A. L.; Noda, L. K.; Pires, A. T. N.; Bertolino, J. R.; Polym. Test. $2004,23,839$.

24. Belfiore, L. A.; McCurdie, M. P.; Das, P. K.; Polymer 2001, 42, 9995.

25. Nakamoto, K.; Infrared Raman Spectra of Inorganic and Coordination Compounds, $5^{\text {th }}$ ed., John Wiley \& Sons: New York, 1997.

26. Cesteros, L. C.; Meaurio, E.; Katime, I.; Macromolecules 1993, $26,2323$. 